\title{
Hubungan Faktor Sosial Petani dengan Penerapan Teknologi Budidaya Padi Hibrida di Kecamatan Pulung Kabupaten Ponorogo
}

\author{
DESYTA YUVITASARI SAPUTRI, I DEWA PUTU OKA SUARDI, \\ IDA AYU LISTIA DEWI \\ Program Studi Agribisnis, Fakultas Pertanian, Universitas Udayana \\ Jl. PB. Sudirman 80323 Bali \\ Email : desytayuvita@gmail.com \\ okasuardi@yahoo.com
}

\begin{abstract}
The Relationship of Social Factors of Farmers with Application of Hybrid Rice Cultivation Technology in Pulung Sub-Distrct of Ponorogo Regency
\end{abstract}

Hybrid rice is a new innovation in agriculture. In its development as an innovation in agriculture, farmers must understand first about how to cultivate hybrid rice because sometimes farmers do not understand how to cultivate hybrid rice properly and correctly. The process of understanding in the implementation of a new innovation by farmers in farming depends on the social factors. This study aims to identify the level of social factors of farmers, to identify the level of application of hybrid rice cultivation technology, and to find out the relationship between social factors with the application of hybrid rice cultivation technology in the Sub-District Pulung of Ponorogo Regency. Sampling was conducted by saturated sampling method. Data analysis method used is descriptive analysis and rank spearman correlation analysis. The result of descriptive analysis shows that the level of social factor of farmers was in the low category with the achievement score of 1.56, while the application level of hybrid rice cultivation technology in Pulung Sub-District was in the medium category with achievement score of 1.96. The result of correlation analysis showed a strong relationship between the social factors with the application of hybrid rice cultivation technology by the correlation value of $0.837 * *$ positive direction of the confidence level at $99 \%$. This means that the higher the level of social factors of farmers, the higher the application level of hybrid rice cultivation technology.

Keywords: social factors, application of technology, relationships

\section{Pendahuluan}

\subsection{Latar Belakang}

Usaha peningkatan produksi pertanian salah satunya diwujudkan melalui pengenalan (introduksi) pertanian modern pada tahun 1969 sejak dilaksanakanya Pelita (pembangunan Lima Tahun) (Utama, 2007).Introduksi pertanian modern menyebabkan banyaknya perubahan yang terjadi terutama didaerah pedesaan. 
Oleh karena itu penggunaan teknologi yang tepat guna sesuai dengan kebutuhan dipersiapkan agar petani mandiri dan mampu memperbaiki kehidupanya.

Sektor pertanian erat kaitannya dengan kebutuhan pangan masyarakat sehingga hal ini menjadi tantangan paling besar di sektor pertanian saat ini untuk memenuhi kebutuhan konsumsi beras nasional dari produksi dalam negeri. Peningkatan ketahanan pangan, solusi berupa inovasi teknologi dalam bidang pertanian dengan menggunakan benih padi hibrida. Kontribusi penggunaan benih unggul bermutu dapat meningkatkan produksi secara signifikan yang terjadi selama ini. Saat ini Kabupaten Ponorogo telah menggunakan teknologi padi hibrida untuk terwujudnya swasembada beras. Pelaksanaan kegiatan penerapan teknologi ini sudah digunakan disalah satu kecamatan yaitu Kecamatan Pulung pada tahun 2010 sampai saat ini yang tersebar di tiga desa yaitu Desa Karangpatihan, Desa Sidoarjo, dan Desa Tegalrejo.

Sebagai sebuah inovasi dalam pengembanganya petani tentu harus memahami terlebih dahulu tentang bagaimana cara membudidayakan padi hibrida, karena penerimaan suatu ide inovasi pada kenyataanya setiap orang tidak akan sama tergantung cara penyampaian, media yang digunakan dan kemampuan petani itu sendiri (Samsudin, 1982). Menurut Yusnita (2010) keberlangsungan petani dalam pengembangan usahatani budidaya padi hibrida dapat dihubungkan dengan sikap mental dan perbuatan petani yang dilandasi oleh faktor sosialnya. Hal ini juga didukung dengan hasil penelitian Sudarmawan (2011) bahwa proses pemahaman dalam penerapan suatu inovasi baru apakah seseorang tersebut dalam menjalankan usahataninya sesuai dengan pedoman PTT tergantung pada faktor sosialnya yaitu: pendidikan (formal ataupun nonformal), pengalaman, kosmopolitan, dan lingkungan sosial, dan penggunaan media massa.

Berdasarkan uraian tersebut dalam penelitian ini mengkaji bagaimana hubungan faktor sosial petani dengan penerapan teknologi budidaya padi hibrida di Kecamatan Pulung Kabupaten Ponorogo.

\section{Metode Penelitian}

\subsection{Lokasi dan Waktu Penelitian}

Lokasi penelitian ini dilakukan di Kecamatan Pulung Kabupaten Ponorogo pada bulan Mei sampai Juni 2016. Pemilihan lokasi dilakukan secara sengaja berdasarkan pertimbangan yaitu (1) Kecamatan Pulung mempunyai agroklimatogis yang sesuai untuk ketentuan pengembangan daerah potensial padi hibrida, (2) Kegiatan pengembangannya berlangsung saat ini.

\subsection{Jenis Data dan Sumber Data}

Data yang dikumpulkan dalam penelitian ini adalah data kuantitatif dan data kualitatif, sedangkan sumber data terdiri dari data primer dan data sekunder. 


\subsection{Metode Pengumpulan Data}

Metode yang diperlukan dalam penelitian ini dikumpulkan dengan menggunakan teknik wawancara, studi pustaka, dan studi dokumentasi.

\subsection{Responden Penelitian}

Populasi dalam penelitian ini adalah seluruh petani budidaya padi hibrida di Kecamatan Pulung Kabupaten Ponorogo yang berjumlah 33 orang. Pengambilan sampel dalam penelitian ini menggunakan metode sampling jenuh dimana penentuan sampel anggota dipilih berdasarkan semua populasi.

\subsection{Variabel dan Metode Analisis}

Variabel yang digunakan dalam penelitian ini adalah variabel faktor sosial (X) yang terdiri dari enam indikator yaitu: pendidikan formal, pendidikan non formal, tingkat kosmopolitan, penggunaan media massa, lingkungan sosial, dan pengalaman. Sedangkan untuk variabel (Y) yaitu variabel penerapan teknologi budidaya padi hibrida terdiri dari lima indikator yaitu: pemilihan varietas, penyiapan lahan, penanaman, perawatan, serta penentuan waktu panen. Data yang telah dikumpulkan terlebih dahulu dianalisis melalui dua pendekatan analisis deskriptif dan analisis korelasi rank spearman. Uji korelasi rank spearman $\left(\gamma_{\mathrm{s}}\right)$ diikemukakan Usman dan Setiady (2008) dengan rumus :

$$
r_{S}=1-\frac{6 b^{2}}{N^{3}-N}
$$

dimana : $\quad r_{s}$ : koefisien korelasi Rank Spearman

$\mathrm{N}$ : jumlah sampel

$\mathrm{b}^{2}$ : selisih antara ranking variabel $\mathrm{X}$ dengan ranking variabel $\mathrm{Y}$

\section{Hasil dan Pembahasan}

\subsection{Karakteristik Responden}

Identitas petani meliputi umur, pendidikan petani, jumlah anggota keluarga, dan penguasaan lahan yang dapat dilihat dari tabel 1 . 
Tabel 1.

Distribusi Responden Berdasarkan Karakteristik Responden

\begin{tabular}{|c|c|c|c|c|}
\hline No & KarakteristikPetani & Kategori & $\begin{array}{c}\text { Jumlah } \\
\text { (jiwa) }\end{array}$ & Persentase \\
\hline \multirow[t]{3}{*}{1} & Umur & a. Muda (30-40 tahun) & 6 & 18 \\
\hline & & b. Sedang (>43-57 tahun) & 4 & 12 \\
\hline & & c. Tua $(>57-70)$ & 23 & 70 \\
\hline \multirow[t]{4}{*}{2} & Pendidikan formal & a. SD & 13 & 40 \\
\hline & & b. SMP & 12 & 36 \\
\hline & & c. SMA & 6 & 18 \\
\hline & & d. S1 atau sederajat & 2 & 6 \\
\hline \multirow[t]{6}{*}{3} & Status penguasaan & a. Penggarap & 6 & 18 \\
\hline & lahan & b. Penyewa & - & - \\
\hline & & c. Pemilik penggarap & 27 & 82 \\
\hline & Luas lahan & a. Sempit $(0,14$ ha- 0,65 ha $)$ & 27 & 82 \\
\hline & & b. Sedang ( $>0,65$ ha- 1,17 ha) & 3 & 9 \\
\hline & & c. Luas (>1,17 ha-1,68 ha) & 3 & 9 \\
\hline \multirow{3}{*}{4} & & a. Sedikit (1-2 orang) & 28 & 85 \\
\hline & Jumian tanggungan & b. Sedang (3 orang) & 4 & 12 \\
\hline & & c. Banyak (4 orang) & 1 & 3 \\
\hline
\end{tabular}

Sumber : Data primer 2016

Tabel diatas menunjukkan karakteristik responden dengan sebagian besar umur responden berada dikategori tua dengan persentase 70\% kisaran umur 57-70 tahun. Menurut Hawkins (1999) dalam penelitianya mengemukakan bahwa orang yang berumur muda atau berusia produktif ternyata tidak menunjukkan lebih inovatif dibanding yang berumur lebih tua. Tabel diatas juga menunjukkan pendidikan formal responden secara keseluruhan berada di tingkat Sekolah Dasar dengan persentase $40 \%$ dikarenakan, rata-rata petani berumur $\geq 60$ tahun. Status penguasaan lahan yang ditunjukkan berada di kategori pemilik penggarap dengan luas lahan rata-rata berada di kategori sempit berkisar antara 0,14 ha sampai 0,65 ha. Sebagian besar petani di Kecamatan Pulung Kabupaten Ponorogo memiliki jumlah tanggungan keluarga sebanyak satu sampai dua orang. Hal ini dikarenakan sebagaian besar anak petani sudah bekerja dan menikah di luar kota dan kemudian menetap dikota tersebut.

\subsection{Identifikasi Tingkat Faktor Sosial Petani Budidaya Padi Hibrida di Kecamatan Pulung Kabupaten Ponorogo}

Karakteristik sosial yang digunakan dalam penelitian ini adalah pendidikan formal, pendidikan non formal, kosmopolitan, penggunaan media massa, lingkungan sosial, dan pengalaman. Penjelasan mengenai distribusi responden yang berhubungan dengan penerapan teknologi budidaya padi hibrida dilihat pada tabel berikut. 
Tabel 2.

Distribusi Responden Berdasarkan Faktor Sosial Petani di Kecamatan Pulung Kabupaten Ponorogo

\begin{tabular}{|c|c|c|c|c|}
\hline No & Variabel & Kategori & $\begin{array}{c}\text { Jumlah } \\
\text { Responden }\end{array}$ & $(\%)$ \\
\hline \multirow[t]{3}{*}{1} & Pendidikan formal & a. Rendah & 27 & 82 \\
\hline & & b. Sedang & 6 & 18 \\
\hline & & c. Tinggi & 2 & 6 \\
\hline \multirow[t]{3}{*}{2} & Pendidikan non formal & a. Rendah & 28 & 85 \\
\hline & & b. Sedang & 2 & 6 \\
\hline & & c. Tinggi & 3 & 9 \\
\hline \multirow[t]{3}{*}{3} & Tingkat kosmopolitan & a. Rendah & 23 & 70 \\
\hline & & b. Sedang & 9 & 27 \\
\hline & & c. Tinggi & 1 & 3 \\
\hline \multirow[t]{3}{*}{4} & Penggunaan media massa & a. Rendah & 25 & 76 \\
\hline & & b. Sedang & 6 & 18 \\
\hline & & c. Tinggi & 2 & 6 \\
\hline \multirow[t]{3}{*}{5} & Lingkungan sosial & a. Rendah & 19 & 58 \\
\hline & & b. Sedang & 13 & 39 \\
\hline & & c. Tinggi & 1 & 3 \\
\hline \multirow[t]{3}{*}{6} & Pengalaman & a. Rendah & 5 & 15 \\
\hline & & b. Sedang & 21 & 64 \\
\hline & & c. Tinggi & 7 & 21 \\
\hline
\end{tabular}

Sumber: Data primer 2016

1. Pendidikan formal

Tabel 2 menjelaskan tingkat pendidikan yang dicapai oleh responden termasuk kategori rendah dengan persentase $82 \%$. Rata-rata pendidikan formal yang ditempuh oleh petani yaitu enam tahun dengan kisaran pendidikan formal antara enam sampai 18 tahun. Hal tersebut dikarenakan usia petani mayoritas berada di kategori lanjut usia.

\section{Pendidikan non formal}

Berdasarkan Tabel 2 pendidikan non formal berada di kategori rendah dengan persentase $85 \%$. Hal ini dikarenakan petani mengikuti kegiatan penyuluhan rata-rata mencapai tiga kali/tahun, dan kegiatan pelatihan rata-rata mencapai satu kali/tahun. Hal ini dikarenakan pemberian pelatihan atau penyuluhan dilaksanakan apabila terkait program baru dari pemerintah dan pendidikan nonformal terkadang kegiatnya berada diluar kota sehingga petani membutuhkan dana secara mandiri. Petani hanya mengirimkan beberapa perwakilannya dari masing-masing kelompok yang bersedia memiliki dana yang cukup untuk mengikuti kegiatan pelatihan dan penyuluhan. 


\section{Kosmopolitan}

Pada Tabel 2 kosmopolitan petani berada di kategori rendah dengan persentase 70\%. Hal ini dikarenakan petani jarang melakukan kegiatan kosmopolitan untuk pergi ke kecamatan lain, kabupaten lain, ataupun pergi ke provinsi lain berkaitan dengan mencari informasi seputar budidaya padi hibrida. Kegiatan kosmopolitan petani sering dilakukan ke kelompok tani lain. Menurut petani informasi yang diperoleh sudah memberikan informasi yang cukup bagi usahataninya.

\section{Penggunaan media massa}

Tabel 2 menjelaskan frekuensi penggunaan media massa termasuk dalam kategori rendah dengan persentase $76 \%$. Hal ini dibuktikan dengan penggunaan media massa petani yang masih rendah, karena petani hanya menggunakan koran "Sinergis" dan majalah "Trubus" yang petani beli secara mandiri. Menurut petani kemampuan yang diperoleh tercukupi dengan pengalaman, diskusi dengan penyuluh, dan menanyakan langsung kepada petani lain melalui diskusi.

\section{Lingkungan sosial}

Tabel 2 lingkungan sosial berada di kategori rendah dengan persentase $58 \%$. Beberapa anggota masyarakat yang membudidayakan padi hibrida yaitu kelompok tani, tetangga, dan kerabat. Hal ini dikarenakan belum semua elemen masyarakat yang ikut berpartisipasi dalam menerapkan usahatani padi hibrida. Elemen masyarakat yang ikut berpartisipasi dalam penggunaan padi hibrida yaitu kelompok tani, tetangga dan kerabat.

\section{Pengalaman berusaha tani}

Tabel 2 pengalaman usaha tani padi hibrida secara kseluruhan berada pada kategori sedang dengan persentase $64 \%$. Hal ini dibuktikan rata-rata pengalaman usahatani padi hibrida yaitu berkisar $>3,3-4,6$ tahun.

\subsection{Identifikasi TingkatPenerapan Teknologi Petani dalam Budidaya Padi Hibrida di Kecamatan Pulung Kabupaten Ponorogo}

Penerapan teknologi budidaya padi hibrida yang digunakan dalam penelitian adalah pemilihan varietas, penyiapan lahan, persiapan pembibitan, tanam pindah, penyulaman, penyiangan, pemupukan, pengendalian hama dan penyakit, serta penentuan waktu panen. Penjelasan lebih lanjut mengenai distribusi responden tentang penerapan teknologi petani dalam budiaya padi hibrida dilihat dalam tabel berikut. 
Tabel 3.

Distribusi Responden Berdasarkan Penerapan Teknologi Budidaya Padi Hibrida di Kecamatan Pulung Kabupaten Ponorogo

\begin{tabular}{|c|c|c|c|c|c|}
\hline No & Variabel & Kategori & $\begin{array}{c}\text { Jumlah } \\
\text { Responden }\end{array}$ & $\%$ & Rata-rata \\
\hline \multirow[t]{3}{*}{1} & \multirow[t]{3}{*}{ Pemilihan varietas } & a. Rendah & 5 & 15 & \multirow{3}{*}{$\begin{array}{c}1,94 \\
\text { (sedang) }\end{array}$} \\
\hline & & b. Sedang & 25 & 76 & \\
\hline & & c. Tinggi & 3 & 9 & \\
\hline \multirow[t]{3}{*}{2} & \multirow[t]{3}{*}{ Penyiapan lahan } & a. Rendah & 1 & 3 & \multirow{3}{*}{$\begin{array}{c}2,30 \\
\text { (sedang) }\end{array}$} \\
\hline & & b. Sedang & 15 & 45 & \\
\hline & & c. Tinggi & 17 & 52 & \\
\hline \multirow[t]{3}{*}{3} & \multirow[t]{3}{*}{ Penanaman } & a. Rendah & 15 & 46 & \multirow{3}{*}{$\begin{array}{c}1,94 \\
\text { (sedang) }\end{array}$} \\
\hline & & b. Sedang & 10 & 30 & \\
\hline & & c. Tinggi & 8 & 24 & \\
\hline \multirow[t]{3}{*}{4} & \multirow[t]{3}{*}{ Perawatan } & a. Rendah & 14 & 42 & \multirow{3}{*}{$\begin{array}{c}1,82 \\
\text { (sedang) }\end{array}$} \\
\hline & & b. Sedang & 16 & 48 & \\
\hline & & c. Tinggi & 3 & 9 & \\
\hline \multirow[t]{3}{*}{5} & Penentuan waktu & a. Rendah & 11 & 33 & \multirow{3}{*}{$\begin{array}{c}1,82 \\
\text { (sedang) }\end{array}$} \\
\hline & \multirow[t]{2}{*}{ panen } & b. Sedang & 17 & 52 & \\
\hline & & c. Tinggi & 5 & 15 & \\
\hline
\end{tabular}

Rata-rata pencapaian skor penerapan teknologi keseluruhan yaitu 1,96 (sedang)

Sumber: Data primer 2016

\section{Pemilihan varietas}

Pemilihan varietas merupakan tingkatan petani dalam memilih varietas unggul dengan beberapa pertimbangan yang dianjurkan oleh pedoman PTT. Pada tahap ini, petani tergolong kategori sedang dengan besar skor rata-rata 1,94. Petani memilih varietas berdasarkan produksi, umur tanaman, pertumbuhan daun dan tanaman, serta kesesuain dengan lingkungan.

\section{Penyiapan lahan}

Tabel 3 yang terjadi pada tahapan ini berada dalam kategori sedang dengan besar skor rata-rata 2,30. Artinya pada tahapan penyiapan belum semua tahapan penyiapan lahan dilakukan sesuai dengan pedoman budidaya. Beberapa tahapan seperti pembersihan galengan petani jarang melakukanya, dan pengistirahatan tanah yang dianjurkan selama satu minggu, petani mempersingkatnya menjadi lima hari. Menurut petani hal tersebut tidak berpengaruh pada hasil panen tanaman padi.

\section{Penanaman}

Pada tahap penanaman secara keseluruhan berada di kategori sedang dengan besar skor rata-rata 1,98. Hal ini dikarenakan ada beberapa anjuran budidaya yang belum sempurna salah satunya adalah penggunaan sistem jarak tanam yang belum 
sesuai. Petani dianjurkan menggunakan sistem legowo karena sistem legowo memberikan manfaat lebih bagi budidaya padi hibrida. Namun petani di Kecamatan Pulung masih menggunakan sistem tegel dengan ukuran 26 x $27 \mathrm{~cm}$.

\section{Perawatan}

Pada tahapan perawatan petani di Kecamatan Pulung berada di kategori sedang dengan besar skor rata-rata 1,82. Hal ini dikarenakan pada kegiatan penyulaman dan kegiatan penyiangan berada di kategori rendah, dikarenakan kedua kegiatan tersebut petani masih belum sesuai dengan yang dianjurkan. Misalnya pada kegiatan penyulaman petani jarang melakukan kegiatan ini, dan pada kegiatan penyiangan petani hanya menggunakan alat yang bernama gasrok dan tidak menggabungkannya dengan pemakaian herbisida.

\section{Penentuan waktu panen}

Pada tahapan penentuan waktu panen di Kecamatan Pulung berada di kategori sedang dengan besar skor rata-rata 1,82. Artinya sebagian besar petani menentukan waktu panen berdasarkan umur padi dengan kriteria berumur 29 hari setelah padi berbunga.

\subsection{Hubungan antara Faktor Sosial dengan Penerapan Teknologi Budidaya Padi Hibrida di Kecamatan Pulung Kabupaten Ponorogo}

Berdasarkan hasil evaluasi pada bagian ini bertujuan untuk melihat sejauhmana hubungan antara faktor sosial dengan penerapan teknologi budidaya padi hibrida dapat dilihat pada tabel dibawah ini.

Tabel 4.

Hasil Analisis Hubungan Faktor Sosial dengan Penerapan Teknologi Budidaya Padi Hibrida di Kecamatan Pulung Kabupaten Ponorogo

\begin{tabular}{lccccc}
\hline \multirow{2}{*}{ Korelasi } & \multicolumn{5}{c}{ PenerapanTeknologiBudidayaPadiHibrida } \\
\cline { 2 - 5 } & Y1 & Y2 & Y3 & Y4 & Y5 \\
\cline { 2 - 5 } & $r s$ & $r s$ & $r s$ & $r s$ & $r s$ \\
\hline $\begin{array}{l}\text { Pendidikan } \\
\text { formal }\end{array}$ & $0,404^{*}$ & $0,503^{* *}$ & $0,588^{* *}$ & $0,607^{* *}$ & 0,278 \\
$\begin{array}{l}\text { Pendidikannonfor } \\
\text { mal }\end{array}$ & $0,474^{* *}$ & $0,404^{*}$ & $0,509^{* *}$ & $0,547^{* *}$ & $0,355^{*}$ \\
Kosmopolitan & 0,337 & $0,534^{* *}$ & $0,545^{* *}$ & $0,578^{* *}$ & $0,444^{* *}$ \\
Penggunaan & $0,558^{* *}$ & $0,459^{* *}$ & $0,793^{* *}$ & $0,771^{* *}$ & $0,425^{*}$ \\
media massa & $0,659^{* *}$ & $0,383^{*}$ & $0,557^{* *}$ & $0,569^{* *}$ & 0,202 \\
Lingkungansosial & $0,446^{* *}$ & 0,263 & $0,683^{* *}$ & $0,617^{* *}$ & 0,290 \\
$\begin{array}{l}\text { Pengalaman } \\
\text { FaktorSosial }\end{array}$ & & & $0,837^{* *}$ & & \\
\hline
\end{tabular}

Sumber: analisis data primer

Berdasarkan Tabel 4 yaitu hasil analisis korelasi secara keseluruhan antara faktor sosial dengan penerapan teknologi padi hibrida menunjukkan adanya 
hubungan sangat signifikan dengan besar nilai korelasi rs $0,837 * *$ pada taraf kepercayaan $99 \%$ searah positif. Artinya semakin tinggi tingkat faktor sosial petani maka semakin tinggi tingkat penerapan teknologi budidaya padi hibrida di Kecamatan Pulung Kabupaten Ponorogo. Hal ini dibuktikan bahwa faktor sosial yang dimiliki petani dari segi pengalaman berusaha tani, penggunaan media massa, tingkat kosmopolitan, pendidikan nonformal, pendidikan formal, dan lingkungan sosial yang pernah petani tempuh dan lakukan masih memiliki peranan dalam penerapan teknologi budidaya padi hibrida di Kecamatan Pulung Kabupaten Ponorogo walaupun dalam menerapkan teknologi budidaya padi hibrida belum maksimal.

\section{Simpulan dan Saran}

\subsection{Simpulan}

Berdasarkan hasil analisis dan pembahasan dapat ditarik kesimpulan bahwa secara umum faktor sosial petani berada dikategori rendah dengan rata-rata skor sebesar 1,56. Kemudian untuk tingkat penerapan sebagian besar berada di kategori sedang dengan besar skor rata-rata 1,96. Hasil analisis antara faktor sosial dengan penerapan teknologi budidaya padi hibrida di Kecamatan Pulung Kabupaten Ponorogo menunjukkan terdapat hubungan yang sangat kuat berdasarkan besar nilai korelasi yaitu $0,837 * *$ pada tingkat kepercayaan $99 \%$ searah positif. Artinya semakin tinggi tingkat factor social petani maka semakin tinggi tingkat penerapan teknologi budidaya padi hibrida di Kecamatan Pulung Kabupaten Ponorogo.

\subsection{Saran}

Berdasarkan pembahasan pada bab sebelumnya, maka saran yang dapat diajukan terkait penelitian adalah rutin mengadakan penyuluhan ataupun pelatihan sehingga tahapan-tahapan pengembangan yang dianjurkan bisa dilakukan petani dengan baik dan benar serta memberikan sosialisasi berkaitan dengan padi hibrida, teknik produksi secara lengkap dan mudah dipahami oleh petani bersedia untuk menerapkan teknologi tersebut yang disesuaikan dengan faktor social petani di Kecamatan Pulung yang sudah diidentifikasi melalui penelitian ini.

\section{Ucapan Terimakasih}

Terimakasih kepada Bapak Suprapto selaku PPL Kecamatan Pulung yang telah membantu peneliti dalam pencarian data penelitian, dan Bapak Bejo Suwito, S.P selaku Kepala Badan Penyuluhan Kecamatan Pulung yang telah memberikan izin penelitian, serta kepada seluruh pihak yang telah memberikan pengarahan bimbingan dan juga dukungan dalam penyelesaian penelitian dan penulisan e-jurnal ini. Semoga penelitian ini dapat berguna dan dimanfaatkan sebagaimana mestinya. 


\section{Daftar Pustaka}

Alim, Syahirul. 2010. Bahan Ajar Penyuluhan Pertanian (Peternakan). Laboratorium Sosiologi Dan Penyuluhan Universitas Padjajaran. Tersedia:http://pustaka.unpad.ac.id/wpcontent/uploads/2011/02/penyuluhanper tanian.pdf. Diakses tanggal 23 Januari 2016.

A, Wawan \& Dewi. 2010. Teori dan Pengukuran Pengetahuan Sikap Dan Perilaku Manusia. Yogyakarta. Nuha Media.

Hadi, Suyanto. 2014. Membangun Ketahanan Pangan Dan Teknologi Produktivitas Pertanian. [online].

Tersedia: http://staff.unila.ac.id/bungdarwin/files/2014/04/kel-3-KETAHANANPANGAN-DAN-TEKNOLOGI-PRODUKTIVITAS.pdf. Diakses tanggal 23 Januari 2016l.

Hermawati, Adya. 2015. Analisis Faktor Konsumsi Bahan Pangan Sumber Protein Berbasis Pendapatan Usahatani Dan Pendapatan Diluar Usahatani. Jurnal Adya UWG JIBEKA. Volume 09, No. 1. http://lp3m.asia.ac.id/wpcontent/uploads/2015/02/1-Jurnal-Adya-UWG-JIBEKA-VOL-9-NO-1-FEB2015.pdf.

Samsudin, U. S. 1982. Dasar-Dasar Penyuluhan dan Modernisasi Pertanian. Bandung. Binacipta.

Sudarmawan, Hari Purnomo Arif. 2011. Hubungan Antara Faktor-Faktor Sosial Ekonomi Petani Dengan Tingkat Penerapan Teknologi Budidaya Padi Organik Di Kecamatan Sambirejo Kabupaten Sragen. Surakarta. Skripsi

Usman, Husaini dan Akbar, R. Purnomo Setiady. 2008. Pengantar Statistika. Jakarta. Bumi Aksara.

Utama, Satria Putra. 2007. Faktor-Faktor Yang Berhubungan Dengan Tingkat Adopsi Petani Pada Teknologi Budidaya Padi Sawah Sistem Legowo Di Kelurahan Dusun Besar Kecamatan Gading Cempaka Kota Bengkulu. Agrisep, 6(1) ejournal.unib.ac.id/index.php/agrisep/article/view/628

Van Den Ban, A.W dan H.S. Hawkins. 1999. Penyuluhan Pertanian. Yogyakarta. Kansisus.

Yusnita, Sari. 2010. Hubungan Antara Faktor-Faktor Sosial Ekonomi Dengan Tingkat Adopsi Inovasi Petani Padi Budidaya Tanaman Jeruk Besar Di Kecamatan Plupuh Kabupaten Sragen. Fakultas Pertanian. UNS. Surakarta. Skripsi 